\title{
Parameter sensitivity study and water property influence: An evaluation of the determining factors on oil drifting effect
}

\section{Estudo de sensibilidade e influência das características da água: Uma avaliação de fatores determinantes no efeito do arraste do óleo}

Nikolas Gomes Silveira de Souza ${ }^{1}$, Jader Lugon Junior ${ }^{2}$, Edna Yamasaki ${ }^{3}$, Ioannis Kyriakides ${ }^{4}$, Antônio José da Silva Neto ${ }^{5}$

\section{ABSTRACT}

The Eastern Mediterranean Sea is a complex location for oil spill trajectory prediction, and accurate results are necessary for emergency response plans. Furthermore, the heavy traffic of the oil shipping industry is associated with an elevated risk of an oil spill. In this work, we have set up a model in MOHID using the Eastern Mediterranean Sea as a reference, setting a simulated oil spill accident at a random location, that is, however, related to ordinary ship trajectories. We have developed a control simulation, varying parameters (wind, API, oil, and water temperature and salinity) to observe how these parameters influence the output and assess the sensitivity of the model. We have found a strong correlation between the wind and the covered area, temperature, and salinity. We have concluded that the wind, API, and water properties were determining factors in these models, with the wind being the strongest influence on the oil drifting effect.

Keywords: MOHID. Modelling. The Mediterranean. Oil. Wind.

\section{RESUMO}

O mar do Mediterrâneo Oriental é um local complexo para predição da trajetória de vazamentos de óleo, e resultados precisos são necessários para planos de resposta a emergências. Além disso, o tráfego intenso de embarcações de transporte de petróleo está associado ao alto risco de um vazamento de óleo. Neste trabalho, construímos um modelo na plataforma MOHID usando o mar do Mediterrâneo Oriental como referência, sendo simulado um vazamento de óleo acidental em um local aleatório associado as trajetórias das embarcações. É desenvolvida uma simulação de controle, alterando parâmetros (vento, API, tipo de óleo, temperatura e salinidade da água) para observar como esses parâmetros influenciam no resultado e avaliar a sensibilidade do modelo. É observada uma forte correlação entre o vento e a área coberta, temperatura e salinidade. Conclui-se que o vento, API, e as características da água foram fatores determinantes nesses modelos, tendo o vento a maior influência no efeito de arraste do óleo.

Palavras-chave: MOHID. Modelagem. Mediterrâneo. Óleo. Vento.

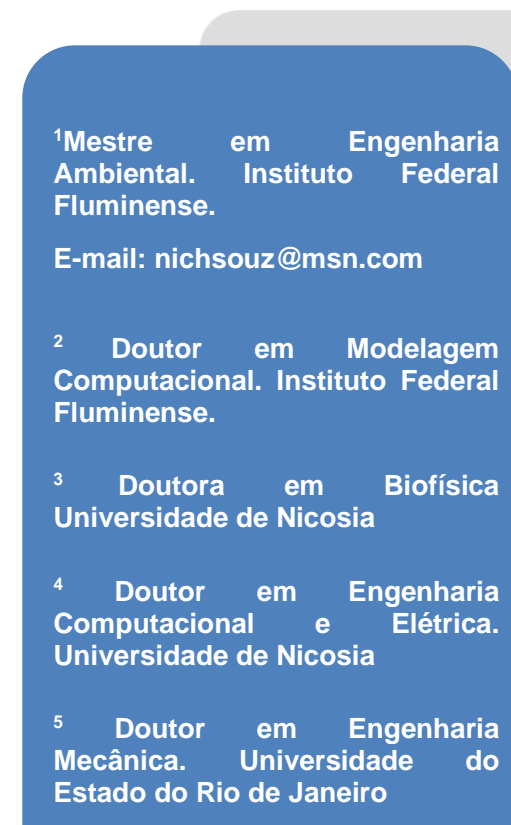

Estado do Rio de Janeiro 


\section{INTRODUCTION}

Several simulation software programs used for decision support in various kinds of environmental emergency responses utilise forecasting to demonstrate how an oil spill propagates throughout the water. Different approaches are used depending on the intention of the researcher (oil spill trajectory prediction, oil spill study case, etc). In an oil spill event, the Lagrangian method is mostly used. It aims at tracking all the particles which will be drifting throughout the ocean, considering the time evolution, regardless of the distance it takes, making it traceable (LONIN, 1999).

MOHID, short for the Portuguese sentence MOdelo HIDrodinâmico (hydrodynamic model), an ANSI FORTRAN-95-based modelling software developed by MARETEC at Instituto Superior Técnico in Lisbon, Portugal (BRAUNSCHWEIG et al., 2004), is an opencode software that allows the user to insert codes and data to perform simulations of desired events (JANEIRO et al., 2012; LI et al., 2017; LUGON JR et al., 2019a, 2019b; MATEUS AND FERNANDES, 2008; MATEUS AND NEVES, 2013; PAIVA et al., 2016, PAIVA et al., 2017; PIERINI et al., 2008). MOHID is a powerful tool to predict oil-spill trajectories. It is equipped with the Lagrangian Module, which can trace the particles of oil along with the hydrodynamic and atmospheric forces. The major advantage of MOHID is the object-oriented programming, which allows the software to combine physical-based transport processes with biogeochemical processes and also the processes derived from hydrographic basins and groundwater (BRAUNSCHWEIG et al., 2004). MOHID accepts input from data mapping institutions since the input extensions are compatible with the software.

In this work, we investigated the atmospheric conditions, the oil parameters, and water properties influence in a simulated oil spill event in the Mediterranean Sea, to evaluate the determining factors on oil drifting effect provided by MOHID.

\section{MODEL IMPLEMENTATION}

The Eastern Mediterranean Sea region was chosen for this simulation as it has a complex bathymetry (ALVES et al., 2015) and intense oil-cargo ship transport (KIRKOS et al., 2017). The Mediterranean water current is commonly referred to as a large thermohaline cell. Different to wind-driven currents and tides, the temperature (thermo-) and salinity (haline) strongly affect the currents rather than any other phenomenon (RAHMSTORF, 2006; UNEP/MAP, 2012; WALDMAN et al., 2018). Based on these assumptions, we ran a total of 
four simulations to identify the model predictions over specific parameters. In simulation \#1, we turned off the wind effect by setting its value to zero. In the second simulation, we forced a heavier oil, although most of the oil transported in the Mediterranean Sea does not reach an API lower than 20 (STURE-ROTTERDAM et al., 2020), we decided for a heavier oil API, as it is commonly referred to be worse than lighter oil spill (IMO, 2010; MU et al., 2019). The third simulation aimed at forcing oil temperature and salinity to different values. Finally, in the last simulation, we decreased the temperature and salinity within the water (value $=0)$, which means there is no concentration of salinity and a significant modification of the temperature. The other parameters were set to control. An overview of the simulation conditions considered can be seen in table 1.

Table 1. Parameters control/modification overview

\begin{tabular}{|c|c|c|c|}
\hline Simulation \# & Properties & Control & Modification \\
\hline$\# 1$ & Wind Effect (On/Off) & ON & OFF (Value $=0$ ) \\
\hline \#2 & API & 20 & 12.9 \\
\hline \#3 & Oil Temperature and Salinity ( ${ }^{\circ} \mathrm{C}$ and $\mathrm{psu}$ ) & $16 / 0.01$ & $10 / 30$ \\
\hline \#4 & Water Temperature and Salinity (On/Off) & ON & OFF $($ Value $=0)$ \\
\hline
\end{tabular}

The simulations were performed in MOHID Studio Professional 2016. The Modules (input scripts for specific interaction components) are listed in Table 2. The atmosphere data was imported from GFS (Global Forecast System) (NOAA, 2015), Hydrodynamics, and Water Properties were imported from Copernicus/Myocean catalogue (CLEMENTI et al., 2019). The dates used for the model simulation are set between 04-August-2019 and 10August-2019. The coordinates for the simulations were randomly set at 32.33 and 34.73 decimal degrees of the Projected World-WebMercator Coordinate system, almost halfway between Cyprus and Israel as can be seen in Fig 1 .

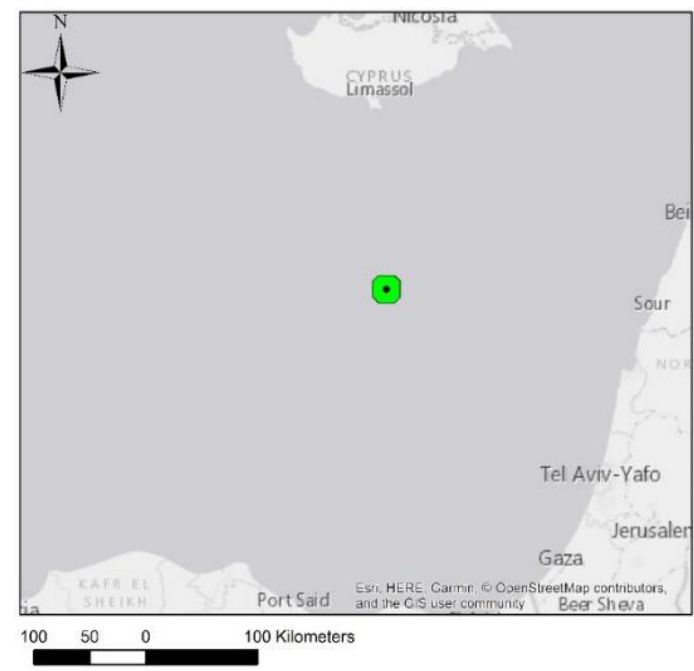

Figure 1 - Oil spill particles origin (black mark inside green area). Made in ARCMAP 10.8 
Table 2. MOHID input modules and definitions.

\begin{tabular}{|c|c|}
\hline Module & Definition \\
\hline Atmosphere & $\begin{array}{l}\text { Atmosphere parameters considered: Wind velocity } \\
\text { components }(\vec{u} \text { and } \vec{v}) \text {, solar radiation, air temperature, } \\
\text { relative humidity, cloud cover, and atmospheric pressure. }\end{array}$ \\
\hline Geometry & $\begin{array}{l}\text { The geometry of bathymetry, which slices in several } \\
\text { layers the whole region. }\end{array}$ \\
\hline Hydrodynamic & $\begin{array}{l}\text { Hydrodynamic parameters considered: water level, } \\
\text { velocity components }(\vec{u} \text { and } \vec{v})\end{array}$ \\
\hline Lagrangian & $\begin{array}{l}\text { The oil properties considering: beaching effect, } \\
\text { instantaneous emission for an accidental event, } \\
\text { advection effects, flowing and floatation effects, constant } \\
\text { turbidity, oil API, oil temperature and salinity, the oil type, } \\
\text { pourpoint, viscosity information. Evaporation, dispersion, } \\
\text { and dissolution effects. }\end{array}$ \\
\hline Model & Simulation time range and model configuration. \\
\hline Tide & Tidal components and configuration. \\
\hline Turbulence & Turbulence parameters. \\
\hline Water properties & Water salinity and temperature concentrations. \\
\hline Waves & Wave parameters and effects. \\
\hline
\end{tabular}

In order to find the determining factors, this paper carried out extensive literature research, coupled with simulations provided by MOHID.

\section{RESULTS AND DISCUSSION}

\subsection{SIMULATION \#1}

The first simulation demonstrated a strong influence of the wind effect on the oil spill. When compared to the control model, it is possible to see a different trajectory happening. The drifting effect is expected in real-life and it is connected to the wind effects. For the Deepwater Horizon accident in the Gulf of Mexico, an attempt to predict the beaching effect was done by modelling the oil drift, which resulted in strong influences caused by currents and wind (LE HÉNAFF et al., 2012).

In Figs 2 and 3 are shown the control and the modified conditions for (ON/OFF) for the wind effect, while in Figs 4 and 5 are shown the last time frames for this simulation. We observed that the trajectory performed by the particles were different, suggesting that different seasons and time ranges would affect the model results. Just as a comparison for a different scenario, a similar conclusion was obtained for the Florida Straits modelling (DROUIN et al., 2019). As the wind changes with time, the model can have numerous outputs, depending on many conditions such as: the time it starts, day, month, and season. 
DOI: 10.18605/2175-7275/cereus.v13n1p186-198
SOUZA, N. G. S; LUGON JR., J; YAMASAKI, E; KYRIAKIDES, I; DA SILVA NETO, A. J.

Parameter sensitivity study and water property influence: An evaluation of the determining factors on oil drifting effect.

Most simulations showed a linear movement in the last 24 and 48 hours toward the continent and making an approximated trendline (yellow arrows) perceivable as in Fig 2, Fig 3, and Fig 5. In Fig 4, the oil trajectory did not show any linear pattern in the last 24 hours, thus, no trendline could be observed.

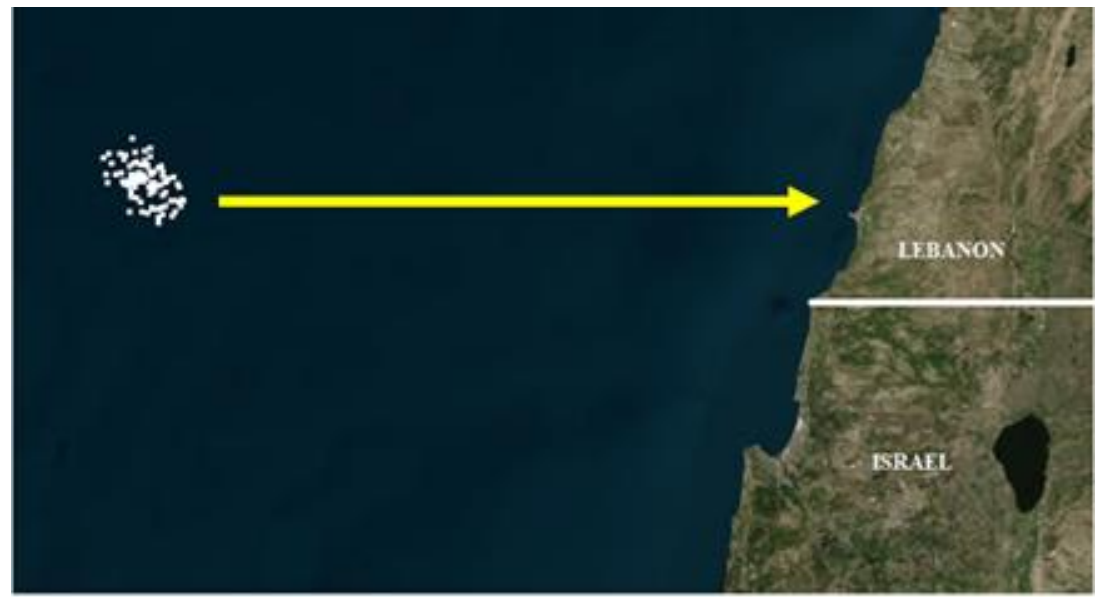

Figure 2. Control simulation: oil particle predominance after 60 hours (oil = white; trend = yellow).

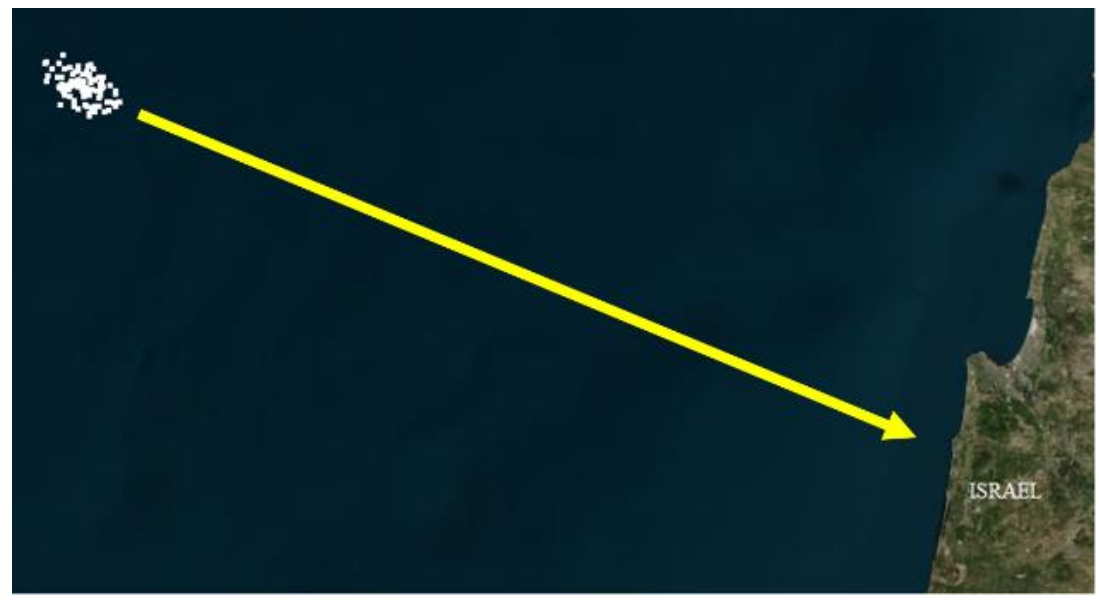

Figure 3. Simulation \#1: Oil particles predominance after 60 hours (oil = white; trend = yellow).

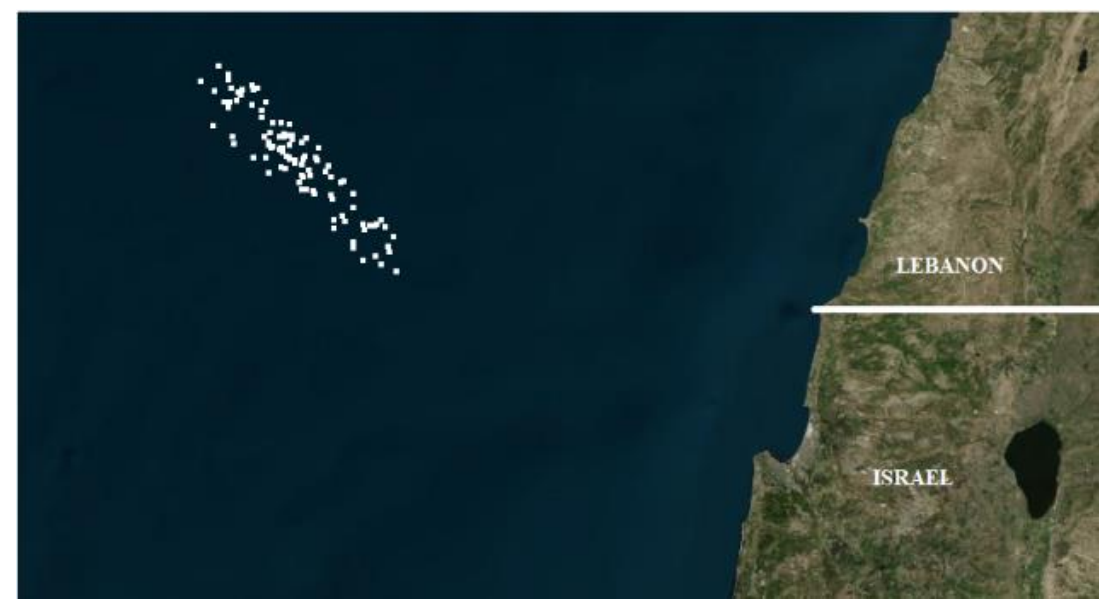

Figure 4. Control simulation: 6 days after the oil spill event (oil = white). 


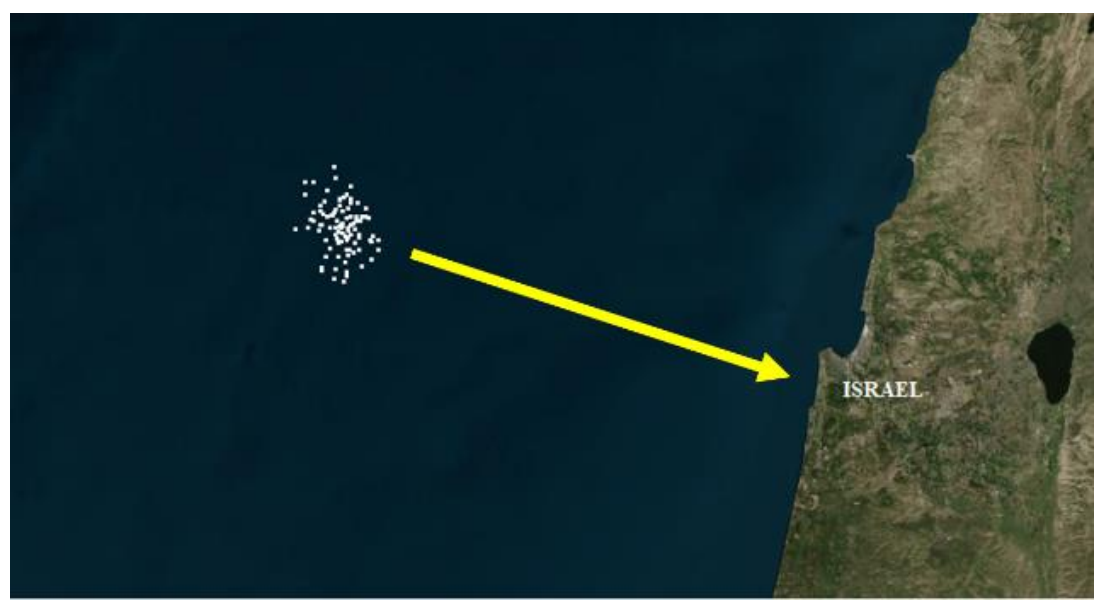

Figure 5. Simulation \#1: 6 days after the oil spill event (oil = white; trend = yellow).

In Fig 2 and Fig 3, during the 60 hour-period after the oil spilt, the ocean current activity had strong influence over the particles movement. Regardless the wind condition, the spread occurred. However, a strong northward force influenced the particles in Fig 2 (Wind on) when compared to Fig 3 (Wind off), which is reasonable, as the wind force is expected to drift the oil particles on the surface of the ocean.

It is not expected that the oil particles shall keep permanent behaviour throughout the entire simulation, as different forces act upon the particles. Thus, the result in Fig 4 was more expected than the one in Fig 5. It is well-known that the wind plays an important role in the spreading and diversification of the trajectory of the oil spill, so the results in Fig 4 and Fig 5 suggest that although the particles are likely to change their position due to hydrodynamic forces, the wind effect could be more significant than hydrodynamic for its trajectory over a longer period of time. In Fig 4, the oil presented a scattered movement throughout the region, which is notable by the odd position of the particles. In Fig 2, Fig 3, the particles form a radial-like format which did not change in the end of the simulation as in Fig. 5. In Fig 4 the particles are presented in a more rectangular format and it was not possible to predict whether it would keep its format. Furthermore, in Fig 4, the last 24 hours presented a constant moment change from circular to linear trend, going in- and backwards. When the wind was set to OFF, the oil had a more linear effect, moving all the particles as a group toward the Continent, as seen in Fig 5.

Figure 6 was plotted to present the computed standard deviation for the area covered by the oil during the 10 simulated days. It is notable that the 72 hours after the oil spill event in the control simulation, the area covered by the oil was intense, decreasing gradually until reaching its flat constancy in Aug, the $7^{\text {th }}$. For simulation \#1, there was no actual difference: suggesting that the plume of oil remained constant during all the period simulated. 


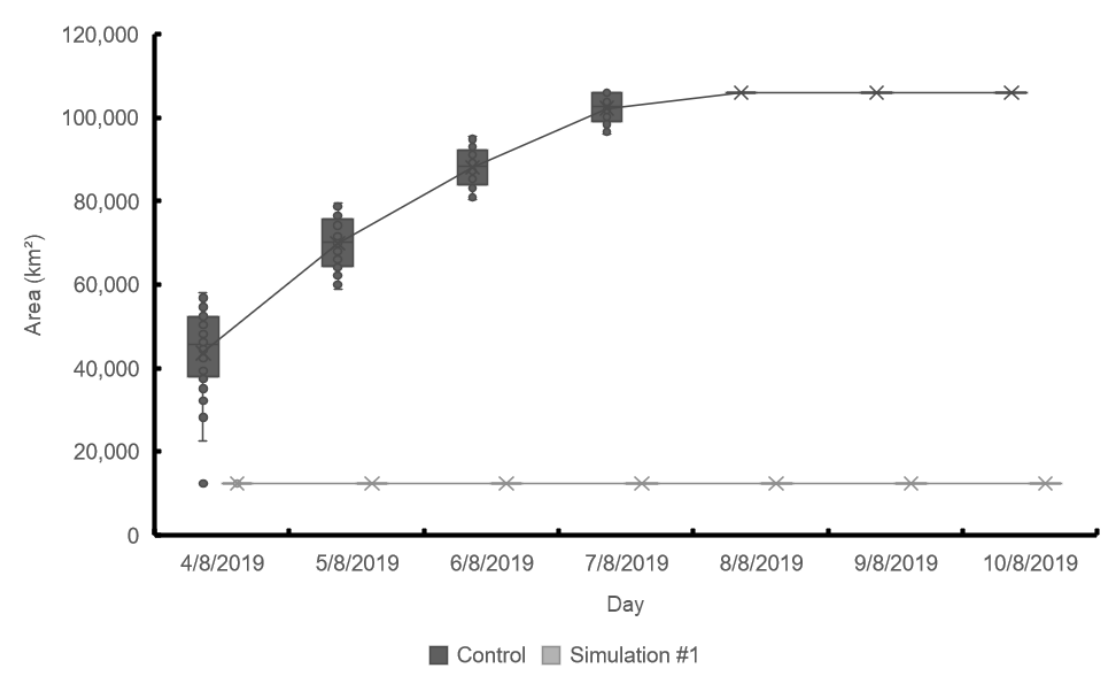

Figure 6. Area covered by the oil in control and simulation \#1.

\subsection{SIMULATION \#2}

In Figure 7, simulation \#2 is coupled with the control within the same output. The model suggested that heavier oil (low API index), tends to spread differently from the control model as heavier fractions are less volatile and less soluble than the lighter ones (ZEINSTRAHELFRICH, 2016). Figure 7, however, could not clarify if viscosity was higher as expected for low-API oils.

Between the control and the simulation \#2, it was observed that the area covered by the oil particles (Fig 8) and viscosity (Fig 9) showed a significant difference with different curves. However, the density kept constant with slightly different values (Fig 10). The relationship between viscosity and density is not direct, however lower API oils tend to have higher viscosities (SANTOS et al., 2014) and this correlation can be observed in MOHID internal modelling equations (RODRIGUES, 2012). 
Figure 7. Simulation \#2 and Control output trajectories (different colours indicate different points. blue $=$ control, API 2 red= simulation \#2, API 12.9).

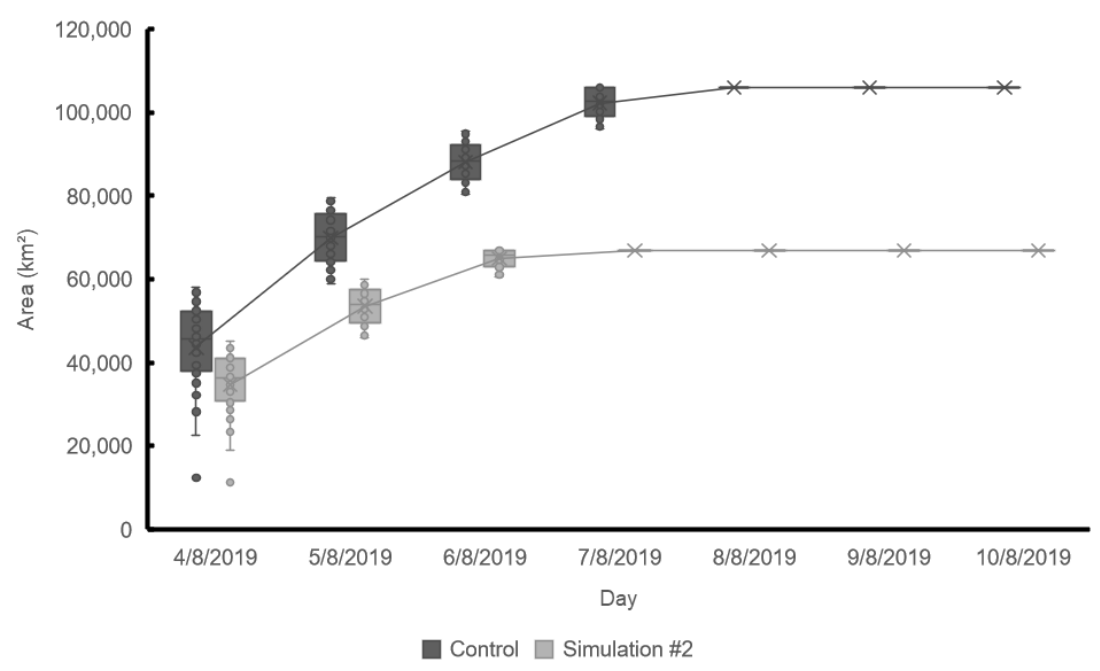

Figure 8. Area covered by the oil in control and simulation \#2.

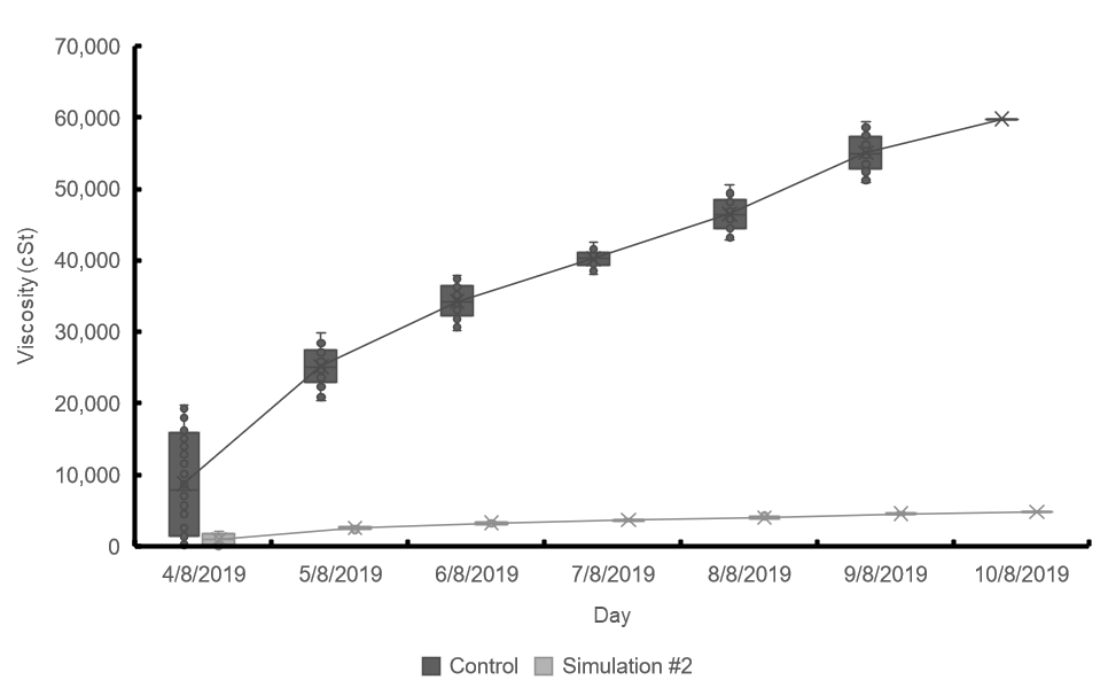

Figure 9. The viscosity of the oil throughout the simulatio processes.

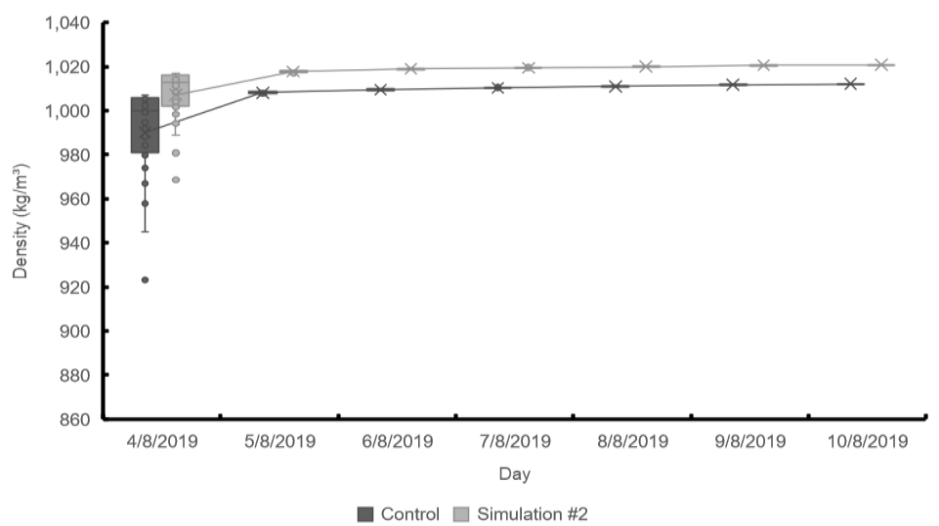

Figure 10. Density output from control and Simulation \#2. 


\subsection{SIMULATION \#3 AND \#4}

Several published works conclude that salinity and temperature are the determining factors for the Mediterranean Ocean current trends (BENSI et al., 2016; CUSINATO et al., 2018; OZER et al., 2017). These factors could affect oil spill trajectory models (WANG et al., 2017). The family of equations in which the MOHID Lagrangian Module is based upon is also in conformity with this assumption, relating oil spread to the temperature (oil and water), oil density (extracted from the API), and water density (RODRIGUES, 2012).

The simulations, at first glance, presented similar positions for the oil particles in simulation \#3 (oil temperature and salinity variation), simulation \#4 (ocean temperature and salinity variation), and in the control, as can be seen in Fig. 11. Nevertheless, the graphs provided by the model, suggest that the ocean temperature and salinity influenced the coverage area of the oil spill (Fig. 12 - Simulation \#4). While the oil salinity and temperature modification graph overwrote the control test, suggesting no difference in the trajectory (Fig.12). In Figure 11, each simulation has a colour of representation. However, only one colour could be seen due to the zoom limitations.

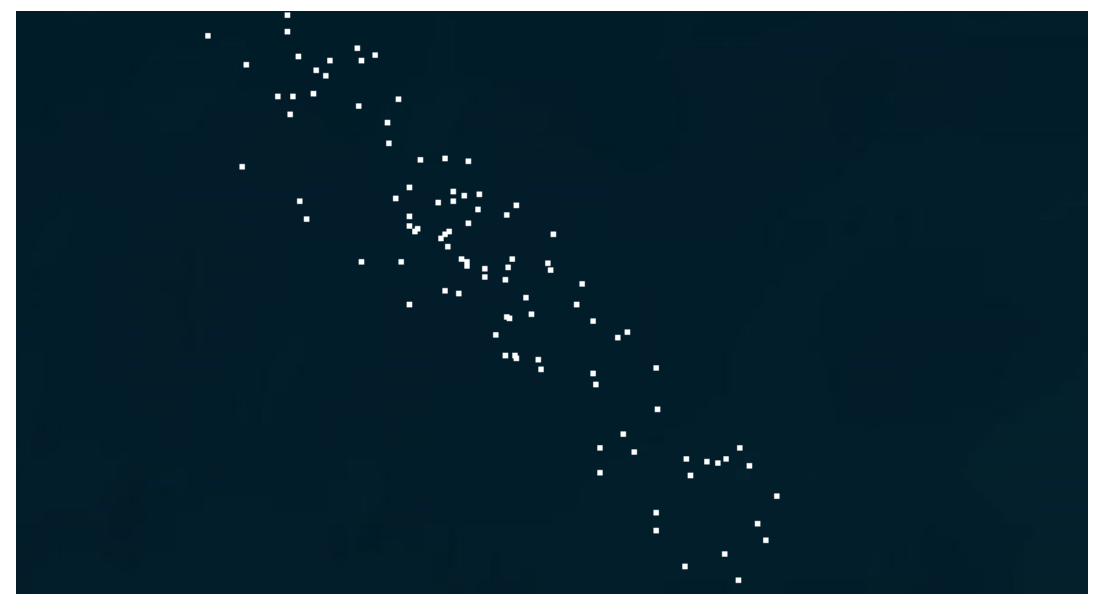

Figure 11. Final stages of the oil trajectory in simulation \#3 (white) and \#4 (green) and control (yellow).

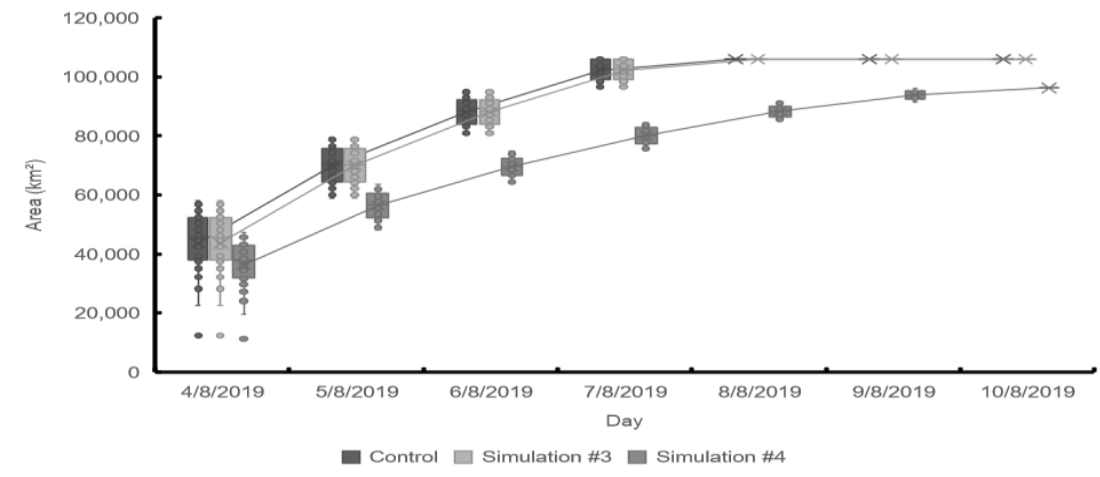

Figure 12. Area covered by the oil in control, simulation \#3 and simulation \#4. 


\section{CONCLUSIONS}

Overall, the model simulations suggested a strong connection between wind and the area covered by the oil after a spill event occurs, reiterating the necessity of accurate data measured by an accredited system.

The API difference could not show a significant difference in the covered area, but instead, it showed a difference in viscosity suggesting that viscosity could be more relevant than the density of the oil particles. It is known that oceanic salinity and temperature play a significant role in the currents in the Mediterranean Sea (BENSI et al., 2016; OZER et al., 2017) and the model agreed with that by showing different trajectories for these parameters. The model, however, showed no significant difference when oil salinity and temperature values for the oil were changed, which may indicate either a software limitation in these parameters for the calculations or no actual interaction between the oil particles features and the oil trajectory. Finally, this work could find a significant difference in the area covered by the oil particles due to the wind. The API index, and water temperature and salinity modifications showed minor influence, however, the model suggests its existence.

Being ready for any unexpected event allows nations to have a better preparedness system. Mathematical models are proved to be beneficial in oil spill predictions, however, many variables are still unclear in how they influence the mechanism of an oil spill event. Summer temperatures and non-summer temperatures are quite different in the Mediterranean area. So, the analysis could also be done at different periods during the year. Further studies following this paper's mains objective using a 3D analysis would be helpful for an enhancement of the existing models.

\section{ACKNOWLEDGEMENT}

This study has been conducted using E. U. Copernicus Marine Service Information for Ocean data and NOAA/NCEP GFS for measured Atmospheric data. Authors acknowledge also the financial support provided by FAPERJ, Fundação Carlos Chagas Filho de Amparo à Pesquisa do Estado do Rio de Janeiro, CNPq, Conselho Nacional de Desenvolvimento Científico e Tecnológico, and CAPES, Fundação Coordenação de Aperfeiçoamento de Pessoal de Nível Superior (Finance code 001)

\section{REFERENCES}

ALVES, T. M. et al. Modelling of oil spills in confined maritime basins: The case for early 
response in the Eastern Mediterranean Sea. Environmental Pollution, v. 206, p. 390399, nov. 2015.

BENSI, M. et al. Effects of the Eastern Mediterranean Sea circulation on the thermohaline properties as recorded by fixed deep-ocean observatories. Deep Sea Research Part I: Oceanographic Research Papers, v. 112, p. 1-13, jun. 2016.

BRAUNSCHWEIG, $F$. et al. The object-oriented design of the integrated water modelling system MOHID. In: Developments in Water Science. [s.I.] Elsevier, 2004. v. 55p. 1079-1090.

CLEMENTI, E. et al. Mediterranean Sea Analysis and Forecast (CMEMS MED-Currents, EAS5 system): MEDSEA_ANALYSIS_FORECAST_PHY_006_013Copernicus Monitoring Environment Marine Service (CMEMS), 2019. Disponível em: $<$ http://marine.copernicus.eu/services-portfolio/access-toproducts/?option=com_csw\&view=details\&product_id=MEDSEA_ANALYSIS_FORECA ST_PHY_006_013>. Acesso em: 12 set. 2020

CUSINATO, E. et al. Mediterranean Thermohaline Response to Large-Scale Winter Atmospheric Forcing in a High-Resolution Ocean Model Simulation. Pure and Applied Geophysics, v. 175, n. 11, p. 4083-4110, nov. 2018.

DROUIN, K. L. et al. Lagrangian simulation of oil trajectories in the Florida Straits. Marine Pollution Bulletin, v. 140, p. 204-218, mar. 2019.

$\mathrm{IMO}$, International Maritime Organization. Manual on oil spill risk evaluation and assessment of response preparedness. 2010. London: International Maritime Organization, 2010.

JANEIRO, J.; MARTINS, F.; RELVAS, P. Towards the development of an operational tool for oil spills management in the Algarve coast. Journal of coastal conservation, $v .16$, n. 4, p. 449-460, 2012.

KIRKOS, G. et al. Oil Pollution in the Waters of Cyprus. In: CARPENTER, A.; KOSTIANOY, A. G. (Eds.). Oil Pollution in the Mediterranean Sea: Part II. The Handbook of Environmental Chemistry. Cham: Springer International Publishing, 2017. v. 84p. 229245.

LE HÉNAFF, M. et al. Surface Evolution of the Deepwater Horizon Oil Spill Patch: Combined Effects of Circulation and Wind-Induced Drift. Environmental Science \& Technology, v. 46, n. 13, p. 7267-7273, 3 jul. 2012.

LI, P. et al. A Comprehensive System for Simulating Oil Spill Trajectory and Behaviour in Subsurface and Surface Water Environments. International Oil Spill Conference Proceedings. Anais...International Oil Spill Conference, 2017

LONIN, S. A. Lagrangian Model for Oil Spill Diffusion at Sea. Spill Science \& Technology Bulletin, v. 5, n. 5-6, p. 331-336, out. 1999.

LUGON JR, J. et al. Lagrangian Trajectory Simulation of Floating Objects in the State of São Paulo Coastal Region. Defect and Diffusion Forum, v. 396, p. 42-49, ago. 2019a.

LUGON JR, J. et al. Application of MOHID platform to simulate the drift of cetaceans stranded in coastal regions. A case study in the Paulista coastline. Revista Cereus, v. 


\section{1 , n. 3,12 nov. $2019 b$.}

MATEUS, M.; FERNANDES, R. Modelling pollution: Oil spills and faecal contamination. Perspectives on integrated coastal zone management in South America, p. 89-96, 2008.

MATEUS, M.; NEVES, R. Ocean modelling for coastal management-Case Studies with MOHID. IST Press http://www. mohid. com/books/2013OceanModellingMOHID. pd, 2013.

MU, L.; WANG, L.; YAN, J. Information engineering of emergency treatment for marine oil spill accidents. 1. ed. Boca Raton: CRC Press, 2019.

NOAA, NATIONAL CENTERS FOR ENVIRONMENTAL PREDICTION/NATIONAL WEATHER SERVICE. NCEP GFS 0.25 Degree Global Forecast Grids Historical ArchiveUCAR/NCAR - Research Data Archive, 2015. Disponível em: <https://rda.ucar.edu/datasets/ds084.1/>. Acesso em: 12 set. 2020

OZER, T. et al. Interannual thermohaline (1979-2014) and nutrient (2002-2014) dynamics in the Levantine surface and intermediate water masses, SE Mediterranean Sea. Global and Planetary Change, v. 151, p. 60-67, abr. 2017.

PAIVA, P. M. et al. Modelagem computacional 3D do blowout de poço de petróleo: revisão sobre requisitos ambientais e metodologia. Boletim do Observatório Ambiental Alberto Ribeiro Lamego, v. 10, n. 1, p. 51, 30 dez. 2016.

PAIVA, P. M. et al. Comparing $3 \mathrm{~d}$ and $2 \mathrm{~d}$ computational modeling of an oil well blowout using MOHID platform - A case study in the Campos Basin. Science of The Total Environment, v. 595, p. 633-641, out. 2017.

PIERINI, J. O. et al. MOHID oil spill modelling in coastal zones: A case study in Bahía Blanca estuary (Argentina). Perspectives on Integrated Coastal Zone Management in South America, IST Scientific Publishers, Lisbon, IST Scientific Publishers, p. 523-528, 2008.

RAHMSTORF, S. Thermohaline ocean circulation. Encyclopedia of quaternary sciences, v. 5, 2006.

RODRIGUES, P. P. G. W. Descrição do MOHID / MARETEC. 1. ed. Campos dos Goytacazes, RJ, Brazil: Essentia Editora, 2012.

SANTOS, R. G. et al. An overview of heavy oil properties and its recovery and transportation methods. Brazilian Journal of Chemical Engineering, v. 31, n. 3, p. 571-590, set. 2014.

STURE-ROTTERDAM, F. et al. Freight Adjustment Factors. p. 27, 2020.

UNEP/MAP. State of the Mediterranean marine and coastal environment. United Nations Environment Programme/Mediterranean action plan (UNEP/MAP)—Barcelona convention: Athens. Anais. 2012

WALDMAN, R. et al. Overturning the Mediterranean Thermohaline Circulation. Geophysical Research Letters, v. 45, n. 16, p. 8407-8415, 28 ago. 2018. 
WANG, Y. et al. Temperature and salinity effects in modeling the trajectory of the 2011 Penglai 19-3 oil spill. Marine Georesources \& Geotechnology, v. 35, n. 7, p. 946-953, 3 out. 2017.

ZEINSTRA-HELFRICH, M. Oil slick fate in 3D: predicting the influence of (natural and chemical) dispersion on oil slick fate. [s.I.] Wageningen University, 21 nov. 2016. 